\title{
Referring to Workers Within Work Disability Prevention Research: Person-First or Identify-First?
}

\author{
Douglas P. Gross ${ }^{1}$ (I) $\cdot$ Teri Slade $^{1} \cdot$ Patricia A. Findley ${ }^{2}$
}

Accepted: 6 January 2022 / Published online: 2 February 2022

(c) The Author(s), under exclusive licence to Springer Science+Business Media, LLC, part of Springer Nature 2022

Workers experiencing injury, disability, or other health conditions often have preferences related to how they are characterized and described. When referring to communities of workers, it is important to be mindful of how the community prefers to be characterized (where there is a preference) and adhere to their preferences. Using incorrect or inappropriate language can be offensive and even stigmatizing [1]. Two styles of language are commonly used: Person-first or Identity-first [2, 3].

Person-first language puts the person before the disability in the description, (e.g., person with work disability or worker with shoulder pain). Person-first language tends to be preferred in communities where people wish to emphasize themselves as a person over the disability or health condition.

Identity-first language uses the common identifier as an adjective, (e.g., disabled worker, deaf worker, autistic worker). In some worker groups, the common identifier is seen as a key part of the group's identity, so putting this identity first in the description is preferred. Generally, the identifier should not be used as a stand-alone term. For example, 'disabled worker' is widely used, whereas 'the disabled' is not. There are exceptions, as some autistic individuals prefer to be referred to as an autistic.

As there is often no clear consensus on what is best [4, 5], the editors of the Journal of Occupational Rehabilitation encourage authors to learn from the populations, workers, and organizations they conduct research with. Referring to workers appropriately involves using the terminology the workers prefer.

\section{References}

1. Dunn DS, Andrews EE. Person-first and identity-first language: developing psychologists' cultural competence using disability language. Am Psychol. 2015;70(3):255-264.

2. Rose I and Fitzpatrick C. Using inclusive language when referring to communities with common identifiers. Springer Nature Editorial Policy Newsletter; 2021.

3. Collier R. Person-first language: noble intent but to what effect? CMAJ. 2012;184(18):1977-1978. https://doi.org/10.1503/cmaj. 109-4319.

4. Botha M, Hanlon J, Williams GL. Does language matter? Identity-first versus person-first language use in autism research: a response to Vivanti. J Autism Dev Disord. 2021;20:1-9. https:// doi.org/10.1007/s10803-020-04858-w.

5. Kenny L, Hattersley C, Molins B, Buckley C, Povey C, Pellicano E. Which terms should be used to describe autism? Perspectives from the UK autism community. Autism. 2016;20(4):442-462. https://doi.org/10.1177/1362361315588200.

Publisher's Note Springer Nature remains neutral with regard to jurisdictional claims in published maps and institutional affiliations.
Douglas P. Gross

dgross@ualberta.ca

1 University of Alberta, Edmonton, AB, Canada

2 Rutgers, The State University of New Jersey, New Brunswick, NJ, USA 